2. Криміналістика : підручник / В.Д. Берназ, В.В. Бірюков, А.Ф. Волобуєв ; за заг. ред. А.Ф. Волобуєва; МВС України. Харків : ХНУВС, 2011. 666 с.

3. Жерж Н.А. Особа злочинця як об’єкт криміналістичного та кримінально-правового вивчення: порівняльно-правовий аналіз. Роль права та закону в громадянському суспільстві : збірник тез наук. доп. Міжнар. наук.-практ. конф., 13-14 лют. 2015 р. Київ, 2015. С. 94-97.

4. Курс криминалистики : в 3 т. / под ред. О.Н. Коршунова, А.А. Степанова. Санкт-Петербург : Юрид. центр Пресс, 2004. Т. 1 : Общетеоретические вопросы. Криминалистическая техника. Криминалистическая тактика. 683 с.

5. Даньшин И.Н. К вопросу о понятии личности преступника. Проблемы социалистической законности. 1980. Вып. 6. С. 117-126.

6. Топольскова I.О. Кримінально-правові та кримінологічні аспекти боротьби з втягненням неповнолітніх у злочинну або іншу антигромадську діяльність : дис. ... канд. юрид. наук : 12.00.08. Луганськ, 2003. 184 с.

7. Коновалова В.Е. Убийство: искусство расследования : [моногр.] Харьков : Факт, $2001.311 \mathrm{c}$. 1988. $160 \mathrm{c}$.

8. Центров Е.Е. Криминалистическое учение о потерпевшем. Москва : Моск. ун-т,

9. Шепітько В.Ю. Особа потерпілого в системі криміналістичної характеристики злочинів. Проблеми законності : респ. міжвідом. наук. збірник / відп. ред. В.Я. Тацій. Харків, 2008. Вип. 93. С. 168-174.

10. Резнікова О.І. Віктимологічне пізнання особи у криміналістиці : автореф. дис. ... канд. юрид. наук : 12.00.09. Харків, 2015. 20 с.

11. Борисенко І.В. Особа потерпілого як елемент криміналістичної характеристики вбивств із розчленуванням трупа. Вісник Харківського національного університету внутрішніх справ. 2006. Вип. 35. С. 142-149.

УДК 343.133

DOI https://doi.org/10.32844/2618-1258.2019.5-2.44

ІЩЕНКО Ю.А.

\title{
РЕАЛІЗАЦІЯ ПІДОЗРЮВАНИМ ПРАВА НА УЧАСТЬ У ПРОВЕДЕННІ ПРОЦЕСУАЛЬНИХ ДІЙ
}

Під правовим статусом будь-якого учасника кримінального провадження в сучасному кримінальному процесі прийнято розуміти визначену процесуальним законом сукупність прав та обов'язків певної особи. У цьому контексті конструкція більшості норм, які в КПК України визначають статус підозрюваного, скоріше відповідає доктрині природнього права, якій властива сама наявність в індивідуума сукупності прав, без притаманного позитивному праву механізму їх реалізації та відповідальності за їх порушення. При цьому останні надбання кримінально-процесуальної науки спонукають шукати шляхи, якими права учасників провадження зможуть бути реалізовані, адже саме можливість практичної реалізації особою своïx прав $€$ важливою складовою частиною права на справедливий суд, визначеного ст. 6 Конвенції про захист прав людини і основоположних свобод.

Варто підкреслити, що відсутність механізмів реалізації права підозрюваного брати участь у процесуальних діях та відсутність законодавчо закріпленої відповідальності за порушення зазначених прав призводять до так званої декларативності статусу підозрюваного в цій частині, що може спричинити порушення основоположних свобод та загалом не відповідає завданням кримінального провадження.

(C) ІЩЕНКО Ю.А. - адвокат, аспірант кафедри криміналістики та кримінального процесу (Академія адвокатури України) 
Зазначені дефекти неможливо виправити без внесення відповідних змін до процесуального закону.

У статті розглянуто основні проблеми забезпечення процесуальних гарантій участі підозрюваного у проведенні процесуальних дій, здійснено огляд та аналіз законодавства, яке регулює порядок реалізації підозрюваним своїх прав.

Метою цієї статті $\epsilon$ аналіз процесуального законодавства, в якому закріплено поняття участі підозрюваного у процесуальних діях та проблемні питання реалізації прав підозрюваного під час участі в таких діях. Із метою дослідження було опрацьовано широкий спектр як вітчизняного, так і міжнародного законодавства, а також здійснено огляд практики його застосування.

У результаті дослідження запропоновані зміни до чинного Кримінального процесуального кодексу України, які дадуть змогу нівелювати проблеми, що виникають під час практичної реалізаціїпідозрюваним права брати участь у процесуальних діях.

Ключові слова: права підозрюваного, слідчі діï, прочесуальні діï, реалізачія процесуальних прав, змагальність, завдання кримінального провадження.

Under the legal status of any participant in criminal proceedings in modern criminal proceedings, it is customary to understand the set of procedural law set of rights and obligations of a certain person. In this context, the construction of most of the norms that determine the status of a suspect in the Code of Criminal Procedure is rather consistent with the doctrine of natural law, which is inherently the very existence of a set of rights in an individual, without inherent positive law mechanism for their implementation and responsibility for their violation. At the same time, the latest acquisitions of criminal procedural science make them look for ways in which the rights of the participants of the proceedings can be exercised, since the possibility of practical realization by a person of their rights is an important component of a fair trial, determined by Art. 6 of the Convention for the Protection of Human Rights and Fundamental Freedoms.

It should be emphasized that the lack of mechanisms for exercising the suspect's right to take part in the procedural actions and the absence of legally enforced responsibility for the violation of these rights, leads to the so-called declarative status of the suspect in this part, which can lead to violation of fundamental freedoms, and in general the violation of fundamental freedoms. proceedings. These defects cannot be corrected without amending the procedural law.

The article deals with the main problems of providing procedural guarantees of the suspect's participation in the procedural actions, reviews and analyzes the legislation that regulates the order of the suspect's realization of his rights.

The purpose of this article is to analyze procedural law, which enshrines the notion of the suspect's involvement in procedural actions and the problematic issues of the suspect's rights to participate in such actions. For the purpose of the study, a wide range of national and international legislation was elaborated, as well as an overview of the practice of its application.

As a result of the research, amendments to the current Criminal Procedure Code of Ukraine are proposed, which will allow to eliminate problems arising during the practical realization of the suspect's right to take part in the procedural actions.

Key words: suspect's rights, investigative actions, procedural actions, realization of procedural rights, competitiveness, task of criminal proceedings.

Вступ. Корінне реформування кримінального процесу в Україні з його орієнтацією на передові досягнення європейської правової науки знайшло своє відображення в суттєвому розширенні прав учасників кримінального провадження. Метою такого реформування стало створення кримінального процесу, заснованого, зокрема, на принципах верховенства права, рівності перед законом і судом та змагальності. Такі докорінні зміни потягли за собою наділення учасників кримінального провадження, зокрема підозрюваного, такими процесуальними правами, які, по-перше, раніше були йому не властиві, а по-друге, в разі їх реалізації в зазначений у процесуальному законі спосіб можуть зашкодити досягненню завдань кримінального провадження. 
У зазначеній статті наводиться аналіз реалізації прав підозрюваного щодо участі в процесуальних діях та пропозиції щодо законодавчого врегулювання проблем, які виникають під час здійснення процесуальних дій за участю підозрюваного.

Розв'язанню проблем прав підозрюваного під час досудового розслідування та їх практичної реалізації присвячені роботи Ю.П. Аленіна, В.П. Бож’єва, Т.В. Варфоломеєвої, В.К. Волошина, В.Г. Гончаренко, Т.М. Добровольської, В.С. Зеленецького, О.В. Капліна, С.О. Ковальчук, О.Ю. Костюченко, О.П. Кучинської, Л.М. Лобойко, П.А. Лупинської, В.Т. Маляренко, М.А. Маркуш, М.М. Михеєнко, Т.М. Мірошніченко, В.В. Назарова, І.Д. Перлова, М.А. Погорецького, Ю.М. Чорноус, В.П. Шибіко, М.Є. Шумило та інших.

Постановка завдання. Метою статті є виявлення прогалин у законодавчому регулюванні реалізації підозрюваним процесуальних прав під час участі у процесуальних діях, а також дослідження проблем, які виникають під проведення процесуальних дій за участю підозрюваного під час здійснення досудового розслідування кримінального провадження.

Результати дослідження. 3 прийняттям у 2012 р. Кримінального процесуального кодексу України [1] почався етап корінного реформування системи кримінально-процесуальних відносин в Україні. Відбулися тектонічні зрушення у розумінні як завдань кримінального провадження, так i ролі учасників кримінального провадження в досягненні цих завдань. У контексті додержання принципу змагальності, процесуальним законом введено таке непритаманне раніше поняття, як інститут сторін кримінального провадження, до яких, зокрема, належать сторона обвинувачення, представлена прокурором, органом досудового розслідування, керівник органу досудового розслідування, слідчим та оперативним підрозділом та сторони захисту, яка представлена підозрюваним, обвинуваченим виправданим та захисником. У процесі реформування сучасний кримінальний процес пройшов кілька етапів становлення, які, своєю чергою, були піддані критиці як вітчизняних науковців, так і практикуючих юристів.

Одним із помітних чинників у сучасному кримінальному процесі України є більш детальна регламентація прав учасників провадження. Порівняно з аналогічними нормами КПК України 1960 р. [2] комплекс прав підозрюваного, обвинуваченого зводився лише до обізнаності з суттю обвинувачення та надання у зв'язку з цим показань, доказів та можливості мати захисника. При цьому змоги самостійно збирати докази, одержувати копії процесуальних документів, знайомитися за матеріалами кримінального провадження до його закінчення та здійснення інших необхідних заходів із метою реалізації права на захист та дотримання дійсно змагального процесу КПК не передбачав. Варто зазначити, що така досить загальна регламентація прав учасників кримінального провадження певною мірою і дотепер зберігається в системах кримінального процесу багатьох країн континентальної системи права. Так, §136 КПК ФРН [3] регламентує, що під час першого допиту обвинуваченому має бути роз'яснено, що, згідно з законом, він на свій розсуд вправі давати пояснення по суті обвинувачення або не давати показання по справі та в будь-який час, у тому числі і до початку допиту може запросити обраного ним захисника. Окрім цього, обвинуваченому має бути роз'яснено, що він на своє виправдання має право заявляти клопотання про представлення певних доказів. У необхідних випадках обвинуваченому має бути також вказано, що він вправі написати свої показання особисто.

Відповідно до ст. 47 КПК Республіки Білорусь [4], обвинуваченому надано право за його клопотанням бути допитаним за участю захисника, давати показання або відмовитися від дачі показань, подавати докази, заявляти про свою винність або невинність, заперечувати проти дій органу кримінального переслідування і вимагати внесення його заперечень до протоколу слідчої або іншої процесуальної дії, що проводиться з його участю, знайомитися з протоколами слідчих та інших процесуальних дій, в яких він брав участь, і робити зауваження з приводу правильності і повноти записів у протоколах, за участю в слідчому або іншому процесуальному дії вимагати внесення до протоколу зазначеної дії записів про обставини, які, на його думку, мають бути окреслені.

Більш детальна регламентація прав підозрюваного у КПК України призвела до появи у процесуальному законі таких не безспірних прав, як право брати участь у проведенні процесуальних дій та право отримувати процесуальні документи.

Так, право брати участь у проведенні процесуальних дій закріплено у п. 9 ч. 3 ст. 42 КПК України [1]. На відміну від поняття слідчих дій, яке встановлено у ст. 223 КПК, згідно з якою слідчими діями є дії, спрямовані на отримання доказів або перевірку вже отриманих доказів [1], поняття процесуальних дій КПК не встановлено. Отже, надаючи оцінку праву брати участь у проведенні процесуальних дій, перш за все варто встановити, що таке процесуальні дії. 
Дослідженню поняття процесуальних дій та його співвідношенню з поняттям слідчих дій вчені присвятили значну кількість наукових робіт. Із системно-семантичного аналізу можна встановити, що поняття «процесуальні дії» є значно ширшим, аніж поняття слідчих дій. Узагальнюючи дослідження науковців у цьому напрямі, можна дійти висновку, що слідчі дії - це, перш за все, процесуальні дії, спрямовані на збирання, перевірку і оцінку відомостей, які мають значення для встановлення обставин, що підлягають доказуванню в кримінальному провадженні. Слідчі дії окремо виділені в процесуальному законі. Зокрема, главою 20 КПК України врегульовано перелік зазначених дій, визначено строки та порядок їх проведення.

Процесуальні дії, за деяким виключенням, не мають такої ретельної регламентації, у зв’язку з чим до процесуальних дій необхідно зарахувати весь перелік передбачених процесуальним законом заходів щодо здійснення як досудового розслідування кримінального провадження, так і його судового розгляду. До таких дій, беззаперечно, мають зараховуватися заходи забезпечення кримінального провадження, дії, які направлені на дотримання прав учасників, процесуальні дії сторони захисту, процесуальні дії під час судового провадження.

При цьому варто зважати на те, що слідчі дії також належать до процесуальних і співвідносяться з останніми як окреме і загальне. Процесуальні дії охоплюють усі передбачені кримінально-процесуальним законодавством заходи, проте відрізняються від слідчих за метою, колом уповноважених суб'єктів і порядком провадження, отримуваними результатами тощо [5, с. 49].

Із зазначеного можна зробити висновок, що під поняттям процесуальних дій варто розуміти всі дії, які здійснюються сторонами, іншими учасниками кримінального провадження, слідчим суддею та судом під час досудового розслідування та судового провадження.

Відповідно до ст. 2 КПК України [1], завданнями кримінального провадження є захист особи, суспільства та держави від кримінальних правопорушень, охорона прав, свобод та законних інтересів учасників кримінального провадження, а також забезпечення швидкого, повного та неупередженого розслідування і судового розгляду, щоб кожен, хто вчинив кримінальне правопорушення, був притягнутий до відповідальності в міру своєї вини, жоден невинуватий не був обвинувачений або засуджений, жодна особа не була піддана необгрунтованому процесуальному примусу і щоб до кожного учасника кримінального провадження була застосована належна правова процедура. Отже, здійснення процесуальних дій, перш за все, має відповідати завданням кримінального провадження.

У цьому аспекті варто звернути увагу на п. 9 ч. 3 ст. 42 КПК України [1], відповідно до якої за підозрюваним закріплено право брати участь у проведенні процесуальних дій. При цьому законодавець під час формулювання цієї законодавчої норми використав таку конструкцію, відповідно до якої право підозрюваного на участь у проведенні всіх без винятку процесуальних дій $€$ безумовним. Зазначена норма не містить ані застереження «в порядку, встановленому законом», ані будь-яких інших обмежень щодо прямого застосування цієї норми. Застосування такої конструкції в реальних умовах може призвести до таких процесуальних колізій, які можуть потягнути за собою невиправдане розширення прав підозрюваного, недобросовісне використання яких стороною захисту призведе до непередбачуваних наслідків

Так, цілком невиправданою із точки зору процесуальної тактики буде участь підозрюваного в допиті потерпілого, безпосередніх свідків злочину та допиті іншого підозрюваного (якщо тільки слідчий не прийме рішення про їх одночасний допит). Водночас може бути доцільною участь підозрюваного або його захисника під час призначення і проведення експертиз.

Очевидно, що праву підозрюваного брати участь у процесуальних діях має відповідати механізм його реалізації, який включав би засоби спонукання сторони обвинувачення до дотримання прав підозрюваного та санкції за їх порушення. Сучасний кримінальний процес серед таких засобів містить лише можливість оскарження рішень, дій чи бездіяльності органів досудового розслідування чи прокурора під час досудового розслідування, яка зазначена у 1 Глави 26 КПК України [1]. Водночас деякі міжнародно-правові акти, крім загального визначення прав потерпілого, містять ще й гарантії їх реалізації. Зокрема, Зводом принципів захисту всіх осіб, які піддаються затриманню чи ув'язненню в будь-якій формі, схваленого резолюцією № 43/173 Генеральної Асамблеї ООН 9 грудня 1988 р., особі в процесі затримання чи зразу ж після затримання уповноважений орган роз'яснює права, а також процедуру реалізації цих прав [6]. Вважаємо, що саме роз'яснення процедури реалізації прав $€$ ключовим чинником, який сприяє дотриманню прав підозрюваного під час кримінального провадження.

Повертаючись до механізмів реалізації прав учасників кримінального провадження, варто зауважити, що ст. 303 КПК України [1] передбачено перелік рішень, дії чи бездіяльності слідчого 
або прокурора, які можуть бути оскаржені під час досудового розслідування. Зазначений перелік $\epsilon$ вичерпним і не містить процесуальної можливості оскарження рішень слідчого або прокурора, пов'язаних із відмовою підозрюваному в участі в окремих процесуальних діях. Вказане призводить до того, що визначена законодавцем змога підозрюваного брати участь у процесуальних діях стає декларативною, а надання підозрюваному такої можливості буде цілком залежати від волі слідчого або прокурора. Порушення ж зазначених прав не потягне за собою жодних правових наслідків.

Висновки. Існування законодавчої неврегульованості та досить загальної визначеності питання участі підозрюваного в проведенні процесуальних дій може призвести до невиправданого залучення підозрюваного до найширшого спектру процесуальних дій, як під час досудового розслідування, так і під час судового розгляду. Залишення без змін такої конструкції (за умови буквального застосування п. 9 ч. 3 ст. 42 КПК України) призведе до порушення розумних строків, надмірного витрачання ресурсів, передчасного розголошення відомостей досудового розслідування, що, своєю чергою, не сприятиме досягненню завдань кримінального провадження. Крім того, відсутність механізму реалізації такої конструкції, а також відсутність відповідальності за їх порушення призведе до необгрунтованого обмеження прав підозрюваного, під час проведення таких процесуальних дій, участь в яких підозрюваного дійсно буде відповідати завданням кримінального провадження.

Подолати зазначені прогалини пропонується шляхом викладення п. 9 ч. 3 ст. 42 КПК України в такій редакції: «брати участь у проведенні процесуальних дій, які проводяться за клопотанням підозрюваного або його захисника».

Зазначене дозволить значною мірою уникнути негативних наслідків, спричинених невдалою конструкцією п. 9 ч. 3 ст. 42 КПК України. Водночас підозрюваному будуть надані додаткові гарантії під час проведення ключових слідчих дій у кримінальному провадженні.

Крім того, керуючись засадами змагальності, з метою реалізації підозрюваним його процесуальних прав, варто передбачити і зміни в КПК України, що стосуються залучення експерта, призначення та проведення експертизи. КПК України пропонується доповнити ст. 243-1 Порядок залучення експерта стороною обвинувачення такого змісту:

«Для залучення експерта стороною обвинувачення складається постанова, в якій, крім даних, зазначених у ст. 110 цього Кодексу, вказуються підстави для проведення експертизи, прізвище експерта або назва установи, експертам якої доручається провести експертизу, питання, 3 яких експерт має дати висновок, об'єкти, які мають бути досліджені, а також перелічуються матеріали, що пред'являються експертові для проведення експертизи. Перш ніж направити матеріали до експертної установи, сторона обвинувачення має ознайомити підозрюваного з постановою про призначення експертизи і роз'яснити йому його права, встановлені цією статтею, про що складається протокол.

При призначенні і проведенні експертизи підозрюваний має право заявити відвід експертові, просити про призначення експерта з числа вказаних ним осіб, просити про постановку перед експертизою додаткових питань, давати пояснення експертові, пред’являти додаткові документи, ознайомлюватися з матеріалами експертизи і висновком експерта після закінчення експертизи.

Обвинуваченому за його клопотанням слідчий може дозволити бути присутнім під час проведення експертом окремих досліджень і давати пояснення».

\section{Список використаних джерел:}

1. Кримінальний процесуальний кодекс України : Закон України від 13.04.2012 p. №4651-VI. ідомості Верховної Ради Украӥни. 2013. № 9-10, № 11-12, № 13. Ст. 88.

2. Кримінально-процесуальний кодекс України : офіц. вид. : станом на 1 груд. 2005 р. $/$ Верховна Рада України. Київ : Парлам. вид-во, 2006. 207 с.

3. Уголовно-процесуальный кодекс Федеративной Республики Германия - Strafprozessordnung (StPO) научно-практический комментарий и перевод текста закона / П. Головенко, Н. Спица / Universitätsverlag Potsdam, 2012. URL: http://opus.kobv.de/ubp/volltexte/2012/6177/pdf/ sdrs02.pdf.

4. Уголовно-процессуальный кодекс Республики Беларусь : Кодекс від 16.07.1999 р. N 295-3. URL: https://etalonline.by/document/?regnum=HK9900295.

5. Чорноус Ю.М. Слідчі дії: поняття, сутність, напрями розвитку та удосконалення : дис. ... канд. юрид. наук : 12.00.09 / НАВСУ. Київ, 2005. 245 с. 
6. Звід принципів захисту всіх осіб, що піддаються затриманню чи ув'язненню у будьякій формі, схвалений резолюцією № 43/173 Генеральної Асамблеї OOH 9 грудня 1988 р. URL: http://zakon.rada.gov.ua/laws/show/995_206 (дата звернення 03.03.2020).

УДК 343.14

DOI https://doi.org/10.32844/2618-1258.2019.5-2.45

КРЕТ Г.P.

\section{СИСТЕМА МІЖНАРОДНИХ СТАНДАРТІВ ФОРМУВАННЯ ДОСТОВІРНИХ ДОКАЗІВ}

Стаття присвячена розкриттю напрацьованих ЄСПЛ міжнародних стандартів достовірності доказів як їх процесуальної властивості. Вказується на загальний підхід ЄСПЛ до оцінки доказів, відповідно до якого вона входить до повноважень національних судів. Звертається увага на обов'язок ЄСПЛ враховувати під час встановлення справедливості провадження у справі питання надання заявнику можливості спростувати достовірність доказів і заперечити проти їх використання та щодо якості доказів і того, чи породжують обставини, за яких вони були здобуті, будь-яких сумнівів щодо їхньої надійності й точності.

Розкривається коло випадків, за яких ЄСПЛ звертається до питання про обгрунтованість здійсненої національними судами оцінки доказів із точки зору їх достовірності. Досліджуються правові позиції ЄСПЛ щодо забезпечення національними судами права обвинуваченого на справедливий судовий розгляд у разі використання свідчень відсутніх свідків, свідчень зі слів інших осіб, свідчень анонімних свідків. Розкриваються правові позиції ССПЛ щодо забезпечення вказаного права у контексті забезпечення національними судами можливості обвинуваченого оскаржити висновки експерта, подані стороною обвинувачення.

Наводяться правові позиції ЄСПЛ щодо неприпустимості використання національними судами для обгрунтування судових рішень свідчень учасників кримінального провадження (зокрема визнавальних свідчень обвинуваченого, свідчень свідків, потерпілих), отриманих за обставин, що свідчать про застосування щодо них катування або нелюдського чи такого, що принижує гідність, поводження.

Викладаються правові позиції ЄСПЛ щодо використання національними судами свідчень учасників кримінального провадження, отриманих за обставин, що вказують на можливу недобровільність їх надання, у тому числі й у випадках подальшої відмови учасників кримінального провадження від таких свідчень або їх зміни. Розкриваються правові позиції ССПЛ щодо неприпустимості обгрунтування національними судами ухвалених ними судових рішень на основі доказів, суперечливість яких не була усунута в ході судового розгляду. На основі проведеного дослідження узагальнюється система міжнародних стандартів формування достовірних доказів, напрацьованих у практиці ЄСПЛ.

Ключові слова: стандарти доказування, міжнародні стандарти доказування, достовірність доказів, стандарти формування достовірних доказів, Європейський суд з прав людини.

The article is devoded to the disclosure international standards for the reliability of evidences as their procedural property, formed by the ECHR. The ECHR's general approach to the assessment of evidences under which it is an authority of national courts is indicated. Attention is drawn to the obligation of the ECHR to take into account, when

(C) КРЕТ Г.Р. - кандидат юридичних наук, доцент, суддя (Касаційний кримінальний суд у складі Верховного Суду) 